\title{
The Impact of the Core Knowledge Curriculum on Creativity
}

\author{
John Baer \\ Rider University
}

ABSTRACT: The Core Knowledge Sequence, which has been proposed as a voluntary national curriculum and has been adopted in many school districts across the United States, is unusually specific about the content students are expected to learn at each grade level. This has led to suggestions that it may promote rote learning and result in a decline in creativity. This possibility was investigated by comparing the creative performance of middle school students who had been attending Core Knowledge schools to that of students at a matched non-Core Knowledge school. There were 3 comparisons: poems written by seventh-grade students, short stories written by seventh-grade students, and short stories written by eighth-grade students. Experts evaluated the creativity of these stories and poems using a consensual assessment technique. Only 1 of the 3 comparisons yielded a statistically significant difference, and that difference favored Core Knowledge students. These results suggest that the Core Knowledge Curriculum and its detailed and specific requirements of content to be studied at each grade level do not negatively impact students' creativity and may even have a positive impact on creative performance in some areas.

The Core Knowledge Sequence (Core Knowledge Foundation, 1998; Hirsch, 1991-1997) is a detailed and specific outline of content in the fine arts, geography, history, language arts, mathematics, and science that has been proposed as one half of a voluntary national K-8 school curriculum (the other half is to be locally determined). The sequence has been adopted by many schools and school districts, and it is especially popular in such educational bellwether states as Colorado, Texas, and Florida, where some large, countywide school districts have adopted the full curriculum for all elementary and middle schools. Its promoters make strong claims for the educational benefits of Core Knowledge, and they have buttressed their claims with a number of studies showing that students in Core Knowledge schools tend to score higher than students in matched non-Core Knowledge schools on standardized scholastic achievement tests (Marshall, 1996, 1998; Schubnell, 1996; Siler, 1997). In an especially significant endorsement, the American School Board Journal called Hirsch's (1996) book, The Schools We Need and Why We Don't Have Them, "the most important book of the past school year" (Harrington-Lueker, 1997, p. 31) in its annual review of the year's best books. In another significant endorsement, the American Federation of Teachers in 1997 gave Hirsch its QuEST Award, citing him for "steadfast commitment to the public schools, to a rich common core curriculum, and to educational equity" (Marshall, 1997, p. 1).

Core Knowledge has not been without its critics. Harrington-Lueker (1997) noted that people "either embrace this book's argument or are thoroughly exasperated by it" (p. 31). Several people have suggested that adherence to the Core Knowledge Sequence will result, at best, in the unthinking, uncritical, and uncreative absorption of knowledge (Orwin \& Forbes, 1994; Schear, 1992; Vail, 1997). One critic called students in Core Knowledge schools "informational blotters" (Paul, 1990, p. 431) and claimed that these students would be able to do very little interesting or productive thinking with the knowledge that they obtained in Core Knowledge schools. The purpose of this study was to investigate the possibility that the

Correspondence and requests for reprints should be sent to John Baer, Rider University, Lawrenceville, NJ 08648. E-mail: baer@rider.edu 
Core Knowledge sequence might depress student creativity.

\section{Method}

To help judge the validity of the fear that Core Knowledge will lead to less creative thinking, experts evaluated the creativity of poems and short stories written by 540 seventh- and eighth-grade students in a Core Knowledge school and a matched non-Core Knowledge school. There is a significant body of research that attests to the validity of using poetry and story writing as indicators of creativity for this age group (Amabile, 1983, 1996; Baer, 1991, 1993, 1996).

\section{Participants}

All the students in the Core Knowledge school had spent at least one year in a school using the Core Knowledge Sequence, and 30\% came from elementary schools that used the Core Knowledge Sequence in all grades. Both middle schools scored above the national average in standardized testing, with the nonCore Knowledge school students' having slightly higher median scores than the Core Knowledge school students in both reading (at the 68th percentile vs. $62 \mathrm{nd}$ percentile of national scores) and mathematics (72nd percentile vs. 70 percentile). The Core Knowledge school had a somewhat larger percentage of minority students. Both schools had approximately $10 \%$ African American students, while the Core Knowledge school had approximately 10\% Hispanic students and the non-Core Knowledge school had just $2 \%$ Hispanic students. Neither school had significant numbers of students of any other minority group. The non-Core Knowledge school had a greater number of students than did the Core Knowledge school.

Students were selected for the study by a random selection procedure that determined which language arts class groups in each school and grade would be assigned which topic. In one of the schools, a group of eighth-grade students also wrote poems, but, because of a mix up, this did not happen in the other school, so those papers were not included in the study. Both schools used heterogeneous grouping in language arts classes (where all writing took place as a regular classroom activity), and students in both groups repre- sented the full range of achievement of students in those schools, with the exception (in both schools) of students who were pulled from language arts to a special education resource room. The writing activities were presented as regular classroom activities, and, therefore, there was no self-selection of participants (i.e., all the students in each class participated).

\section{Materials and Procedures}

There were three groups of papers: 214 eighthgrade students wrote short stories (Core Knowledge $N=87$, non-Core Knowledge $N=128$ ), 138 seventhgrade students wrote short stories (Core Knowledge $N=60$, non-Core Knowledge $N=78$ ), and $188 \mathrm{sev}$ enth-grade students wrote poems (Core Knowledge $N=59$, non-Core Knowledge $N=129$ ). The subject of the poem was to be "The Wind." Students writing stories were given a visual prompt and told that they should include the two children in that drawing in some way in the story. Students were encouraged to write interesting and imaginative poems and stories. They were told that their papers would be read (by their teacher), but that they would not be graded. They were not told the purpose of the study, or even that they were part of a study, until after all papers had been collected. In all cases, the writing activity was presented as a regular language arts classroom activity.

Expert judges, all of whom were accustomed to reading the work of middle school students, rated the stories and poems independently on a 1.0-5.0 scale, using Amabile's (1982) Consensual Assessment Technique. The sole criterion was creativity. There were four judges for the poems and four for the stories. All were experienced writers and teachers; two were editors of literary magazines; and two had recently served as judges for a high school poetry contest. To avoid systematic effects of the order of reading, each judge was given the poems or stories in a different order.

\section{Results and Discussion}

Interrater reliabilities were acceptable for group comparisons, with coefficient alphas of .83 for the eighth-grade stories, .79 for the seventh-grade stories, and .77 for the seventh-grade poems.

There were three comparisons, only one of which yielded a statistically significant difference. The 
Table 1. Comparisons of Group Means

\begin{tabular}{|c|c|c|c|c|c|c|c|c|}
\hline \multirow{2}{*}{$\begin{array}{l}\text { Age and } \\
\text { Study Group }\end{array}$} & \multicolumn{2}{|c|}{ Control Group } & \multicolumn{2}{|c|}{ Core Knowledge } & \multirow[b]{2}{*}{$F$} & \multirow[b]{2}{*}{$p$} & \multirow{2}{*}{$\begin{array}{l}\text { Effect Size: } \\
\text { Cohen's } d\end{array}$} & \multirow[b]{2}{*}{ Effect-Size $r$} \\
\hline & $M$ & $S D$ & $M$ & $S D$ & & & & \\
\hline $\begin{array}{l}\text { Seventh- } \\
\quad \text { Grade Stories }\end{array}$ & 2.41 & .85 & 2.99 & .93 & $14.81(1,136)$ & .0002 & .66 & .31 \\
\hline $\begin{array}{l}\text { Seventh- } \\
\text { Grade Poems }\end{array}$ & 2.76 & .99 & 2.81 & .73 & $.12(1,212)$ & .73 & .05 & .03 \\
\hline $\begin{array}{l}\text { Eighth- } \\
\text { Grade Stories }\end{array}$ & 2.95 & 1.04 & 2.71 & 1.02 & $2.61(1,186)$ & .11 & .22 & .11 \\
\hline
\end{tabular}

seventh-grade Core Knowledge students' stories had a mean creativity rating of 2.99 compared to the nonCore Knowledge students' $2.41, F(1,136)=14.81$, $p=.0002$. The eighth-grade non-Core Knowledge students' stories had a somewhat higher mean creativity (2.95) rating than the Core Knowledge students' stories (2.71), but this difference was not statistically significant. The difference between the creativity ratings of the poems was small: 2.81 for the Core Knowledge group and 2.76 for the non-Core Knowledge group. All group means, standard deviations, comparisons ( $F$ and $p$ ), and effect sizes (Cohen's $p$ and effect-size $r$ ) are reported in Table 1.

The charge that students attending Core Knowledge schools are likely to become less creative thinkers was not substantiated by these data; in fact, to the degree that one group gave evidence of greater creativity, it was the Core Knowledge group, although only in one of three comparisons. This study provides no support for those who fear that an elementary and middle school curriculum based on the Core Knowledge Sequence is detrimental to the development of students' creativity.

There is one other issue that this study addresses, although only very indirectly. The question of the importance of detailed content knowledge in creative performance has often been raised in the context of expert-level creativity (Chase \& Simon, 1973; Gruber, 1981; Larkin, McDermott, Simon, \& Simon, 1980; Mayer, 1983; Simonton, 1994; Tardif \& Sternberg, 1988). It has also been suggested that extensive knowledge can actually decrease creativity and problemsolving skill, because such knowledge can interfere with the generation and/or acceptance of new ideas (Bernstein, Roy, Srull, \& Wickens, 1991). Guilford's Structure-of-the-Intellect model (Guilford, 1967; Guilford \& Hoepfner, 1971) differentiated (a) divergent production, which was posited to be a key component of creativity; (b) convergent production, which was not theorized to be central to creative thinking, although assessments of these abilities have shown a significant correlation between divergent and convergent thinking (Baer, 1993); and (c) evaluation, which has also not been considered a key component in creativity, but has been getting much more attention among creativity theorists of late (see Runco, in press).

There is evidence from previous research that students studying in Core Knowledge schools tend to show greater achievement on standardized tests (Marshall, 1996, 1998; Schubnell, 1996; Siler, 1997), which generally assess convergent, right-answer kinds of thinking. The equivalent, or slightly higher, creative performance by Core Knowledge students in this study suggests that giving more attention to acquiring detailed content knowledge (and to getting the right answer) does not necessarily depress creativity. It may, in fact, increase it, at least when one is looking at everyday, garden-variety creative performance.

\section{References}

Amabile, T. M. (1982). Social psychology of creativity: A consensual assessment technique. Journal of Personality and Social Psychology, 43, 997-1013.

Amabile, T. M. (1983). The social psychology of creativity. New York: Springer-Verlag.

Amabile, T. M. (1996). Creativity in context: Update to the social psychology of creativity. Boulder, CO: Westview.

Baer, J. (1991). Generality of creativity across performance domains. Creativity Research Journal, 4, 23-39.

Baer, J. (1993). Divergent thinking and creativity: A task-specific approach. Hillsdale, NJ: Lawrence Erlbaum Associates, Inc.

Baer, J. (1996). The effects of task-specific divergent-thinking training. Journal of Creative Behavior, 30, 183-187.

Bernstein, D. A., Roy, E. J., Srull, T. K., \& Wickens, C. D. (1991). Psychology (2nd ed.). Boston, MA: Houghton-Mifflin.

Chase, W. G., \& Simon, H. A. (1973). Perception in chess. Cognitive Psychology, 4, 55-81. 


\section{J. Baer}

Core Knowledge Foundation. (1998). Core Knowledge Sequence. Charlottesville, VA: Author.

Gruber, H. E. (1981). Darwin on man: A psychological study of scientific creativity (2nd ed.). Chicago: University of Chicago Press.

Guilford, J. P. (1967). The nature of human intelligence. New York: McGraw-Hill.

Guilford, J. P., \& Hoepfner, R. (1971). The analysis of intelligence. New York: McGraw-Hill.

Harrington-Lueker, D. (1997). The year's best books. American School Board Journal, 184(8), 31-34.

Hirsch, E. D., Jr. (Ed.). (1991-1997). The Core Knowledge series: Resource books for kindergarten through six. New York: Doubleday.

Hirsch, E. D., Jr. (1996). The schools we need and why we don 't have them. New York: Doubleday.

Larkin, J. H., McDermott, J., Simon, D. P., \& Simon, H. A. (1980). Expert and novice performance in solving physics problems. Science, 208, 1335-1342.

Marshall, M. (1996). Core Knowledge Sequence credited in test score boosts. Common Knowledge, 9(4), 3-5.

Marshall, M. (1997). Hirsch receives AFT's QuEST Award. Common Knowledge, 10(3), 1.

Marshall, M. (1998). Core schools outperform state test averages in Maryland. Common Knowledge, 11(1), 1-9.

Mayer, R. E. (1983). Thinking, problem solving, cognition. New York: Freeman.
Orwin, C., \& Forbes, H. D. (1994). Cultural literacy: A Canadian perspective. International Journal of Social Education, 9(1), 15-30.

Paul, R. W. (1990). Critical and cultural literacy: Where E. D. Hirsch goes wrong. In R. W. Paul \& A. J. A. Binker (Eds.), Critical thinking: What every person needs to survive in a rapidly changing world (pp. 429-435). Rohnert Park, CA: Center for Critical Thinking and Moral Critique, Sonoma State University.

Runco M. A. (Ed.). (in press). Critical creative processes. Cresskill, NJ: Hampton Press.

Schear, E. L. (1992). Cultural literacy and the developmental student: Whose culture and what kind of literacy? Research and Teaching in Developmental Education, 8(2), 5-14.

Schubnell, G. O. (1996). Hawthorne Elementary School: The evaluator's perspective. Journal of Education for Students Placed at Risk, 1(1), 33-40.

Siler, J. N. (1997). Special education students thrive on Core. Common Knowledge, 10(4), 3-7.

Simonton, D. K. (1994). Greatness: Who makes history and why. New York: Guilford.

Tardif, T. Z., \& Sternberg, R. J. (1988). What do we know about creativity? In R. J. Sternberg (Ed.), The nature of creativity (pp. 429-440). Cambridge, UK: Cambridge University Press.

Vail, K. (1997). Core comes to Crooksville. American School Board Journal, 184(3), 14-18. 